Acta Horticulturae et Regiotecturae - Special Issue

Nitra, Slovaca Universitas Agriculturae Nitriae, 2016, pp. 18-24

\title{
INVESTIGATION OF THE OPTIONS TO EXTEND THE PERIOD OF MARKET SUPPLY WITH FRUITS OF CAPE GOOSEBERRY (PHYSALIS PERUVIANA L.)
}

\author{
Nikolay PANAYOTOV*, Ani POPOVA \\ Agricultural University-Plovdiv, Bulgaria
}

\begin{abstract}
The main goal of the present study was to establish the opportunity for prolonged obtaining and supplying with cape gooseberry (Physalis peruviana L.) through application of various technological means. Experiments were carried out with two varieties of cape gooseberry - Plovdiv and Obrazec 1 . The plants were grown by three different technologies - by pricking out seedlings, not pricking out seedlings and direct outdoor sowing, with three different sowing periods with interval of each being 15 days. The whole period of obtaining the production from each variant was investigated. In additional experiments, there were established the possibilities for storage of the fruit and also the period of supplying the market as well as additional post harvest ripening. The obtaining of the production from direct harvests starts from plants grown with pricking seedlings in the second decade of August to mid - October, those with no pricking seedlings from the first ten days of September to late October and with direct seeding from the beginning to the end of October. Plovdiv variety is characterized by rather high ripe. By storage, depending on the type of farming, the production comes from mid - September to early January, and in some periods coincides with fruits from additional ripening.
\end{abstract}

Keywords: seedling, outdor sowing, storage, post-harvest, maturity

The cape goosebery fruits according to the opinion of Caravalho (2015) and also of Ramadan and Moersel (2007) are one of the most promising exotic fruits for fresh consumption and for canning industry. Jaeger (2001) reported, that the cape gosberry market in Europe is not very large, it is estimated at 2000 to 2500 tonnes, but the interest is constantly growing. The main share of the fruits in Europe are imported from Columbia. The scale and speed of change in the fresh production distribution of northern Europe has been exceptional, and the supermarkets and hypermarkets now control $70 \%$ of the grocery retail trade. Similar conclusions were also posted by Ramadan (2011), and he emphasized that the popularity of cape gosberry is rapidly growing.

Cape gooseberry is characterized with good capacity for post-harvest ripening and storage. These two aspects are one of its main economic meanings, frequently used in practice. Through them, the increase of market supply with production, revenue growths, resulting in increased efficiency of production are achieved. In order to equalize the degree of ripeness may be allowed 2-3 weeks for post-harvest ripening. At low atmospheric humidity its fruits can be stored 1-2 months, and in the refrigerator at $2{ }^{\circ} \mathrm{C}-$ up to $4-5$ months (Christov, 2010). Plants can be grown as seedlings- prick out as well as non prick out and also by direct outdoor sowing (Cherenok, 1997). Development of the plants of vegetable crops is directly related to the applied technology, farming method and time sowing or planting (Ivanova et al., 2014; Shopova et al., 2014; Shopova et al., 2014a).

Morton (1987), McCain (1993) and Sarkar et al. (1993) pointed out that the post-harvest period of fruits of cape gooseberry is relatively long, a few months when they are stored with shell in dry conditions. Also the opinion of Klinac and Wood (1986) is similar, they successfully stored the fruits with shell at a temperature below $2^{\circ} \mathrm{C}$ for $4-5$ months. Panayotov and Pevicharova (2002) stored in the refrigerator fruits of cape goosebery in very good conditions for up to 50 days, and outdoors up to 40 days, while in outdoor storage the losses are very high.

As an indicator for maturity Fisher et al. (2011) recomended to be used the calix and colour of fruit. They also reported that its climacteric fruits and the husk prevents early breakdown. The fruits withstand temperatures as low as 1 to $2^{\circ} \mathrm{C}$, which favours long-term storage. Physalis fruits are stored remarkably well. If the calyx is intact, the fruit can be held for four to five months at $2{ }^{\circ} \mathrm{C}$. Long storage times are also reported for temperatures up to $18{ }^{\circ} \mathrm{C}$, provided a low humidity is maintained (Jaeger, 2001). In the storage of fruits of cape gooseberry at different temperatures ranging from $0{ }^{\circ} \mathrm{C}$ to $20^{\circ} \mathrm{C}$. Peiris et al. (1999) found out that with increasing temperature, the intensity of respiration increased exponentially and the divisions of carbon dioxide varied. The physals fruits according to Patel (2011) possess high specific activity of hydrolyzing and antioxidant enzymes, while the activity of cell wall-degrading enzymes is relatively low and these facts indicate a better postharvest storage life. Hence, the cape gooseberry, which is an underutilized fruit, may be considered for commercial exploitation.

The main goal of the present study was to investigate different ways and agri-cultural practice for prolonging the period for supplying with fruit production of cape gooseberry (Physalis peruviana L.) 


\section{Material and methods}

The experiment was carried out in the Scientific fields and laboratories of the Department of Horticulture at the Agricultural University - Plovdiv, Bulgaria during the period 2008-2010. The varieties Plovdiv (first Bulgarian cape gooseberry variety) and Obrazec 1 were used in this study. Different agricultural approaches and technics, results of three different separate experiments, such as the type of seedling and term for sowing; storability and post-harvest ripening were studied and summarized in this study.

The plants were grown by three techological methods: pricking out seedlings, non pricking outh seedling and direct out door sowing.

The seeds for pricked out seedlings were sown in enriched peat mixture in a heated glasshouse three times during the interval of 15 days - 1 February, 15 February and 2 March at $1.8 \mathrm{~g} \mathrm{~m}^{-2}$, and the sowing rate for hectare was $80 \mathrm{~g}$. In the phase of the first pair of true leaves, seedlings were pricked in pots no. 10 in the same enriched peat mixture in plastic house. After running the risk of last spring frost, and development of 10-12 true leaf, the plants were planted in rows by the distances $70 \times 50 \mathrm{~cm}$ (Panayotov and Tcorlianis, 2000).

Non pricked out seedlings were produced in a nonheated plastic green house on the bed with terms of sowing 1 March, 15 March and 30 March with the same rates of sowing per hectare, while for a square meter it was $1.2 \mathrm{~g}$ and the seeds were covered with enriched peat mixture. Planting was done in the middle of May when the plants were with 7-8 true leaves by the scheme $70 \times 50 \mathrm{~cm}$.

The direct sowing outside was implemented in following terms: 1 April, 15 April and 30 April with sowing rate from
$150 \mathrm{~g} \mathrm{ha}^{-1}$ and with 4-5 seeds in a cluster by the scheme $110+50 \times 50 \mathrm{~cm}$ and the plants were thinned in the phase of two true leaves.

The experimental plot was $8 \mathrm{~m}^{2}$ and the experiments were carried out in four replications. During vegetation each agro-technological practice necessary were applied. At maturity, regularly harvests are carried out.

From the last harvest before the first autumn frosts, average samples of $500 \mathrm{~g}$ ripe and healthy fruit, with no signs of illness or injury in four iterations set for storage at ambient conditions in plastic crates with a capacity of $3 \mathrm{~kg}$. The interval of seven days was accounted the percentage of preserved fruits (losses). All decayed and diseased fruits were removed. Accounting continued to 49 days, at residue of fruit less than ten percent.

At the end of the growing season, before the first autumn frost, well-formed fruits with normal size, but unripe, undamaged and illnesses were harvested and placed for after harvest ripening. It was carried out in four replications, in ambient conditions in storage house with temperature $20-22{ }^{\circ} \mathrm{C}$ and $60-65 \%$ air humidity. The fruits in quantity of $500 \mathrm{~g}$ were placed in plastic, very good disinfected boxes with depth of layer of $7-8 \mathrm{~cm}$. Through periods of 7 days until depletion of healthy fruit, the ripe fruits were taken, while the rotting and damaged ones were removed. The first autumn frosts during the study occurred between October 15 to 23.

Data of the study was subject to analysis of variance, and least significant differences between means were calculated by the Fisher test at $p=0.05$ (described by Fowel and Cohen, 1992). In this article the results of three separately experiences are summarized and compared. The presented data are mean values from the three years of the investigation periods, because the trends were similar.

Table 1 Productivity on cape gooseberry in different way for growing $\left(\mathrm{kg} \mathrm{ha}^{-1}\right)$

\begin{tabular}{|c|c|c|}
\hline \multirow[t]{2}{*}{ Variants } & \multicolumn{2}{|c|}{ Varieties } \\
\hline & Plovdiv & Obrazec 1 \\
\hline \multicolumn{3}{|c|}{ Prick out seedlings } \\
\hline 1.02 & 3508.8 & 2253.0 \\
\hline 15.02 & 3328.6 & 1873.2 \\
\hline 2.03 & 2825.8 & 1840.1 \\
\hline $\operatorname{LSD} p=0.05$ & 111.8 & 426.0 \\
\hline \multicolumn{3}{|c|}{ Non-pricking out seedlings } \\
\hline 1.03 & 3614.7 & 2891.3 \\
\hline 15.03 & 3874.5 & 3332.7 \\
\hline 30.03 & 2751.1 & 2871.2 \\
\hline LSD $p=0.05$ & 968.0 & 347.1 \\
\hline \multicolumn{3}{|c|}{ Direct outdoor sowing } \\
\hline 1.04 & 3350.2 & 3051.6 \\
\hline 15.04 & 3418.4 & 3294.2 \\
\hline 30.04 & 3870.5 & 3418.4 \\
\hline LSD $p=0.05$ & 160.9 & 130.4 \\
\hline
\end{tabular}




\section{Results and discussion}

Through different ways of growing of the plants from cape goosebery, changes in productivity and periods of harvest of the fruits are observed. Novoa et al. (2016) emphasised that it is necessary to implement appropriate technologies and improve postharvest handling operations, in order to obtain fruit of excellent quality and guarantee it for marketing, avoiding high product losses. In Table 1 there are presented data for yield, depending on the technology. It is noteworthy that higher productivity is characteristic for the variety Plovdiv. Most high-yield in prick out the seedlings is obtained by date of sowing 1 February - for Plovdiv it is $3508.8 \mathrm{~kg} \mathrm{ha}^{-1}$, and on the other genotype it is $2253.0 \mathrm{~kg} \mathrm{ha}^{-1}$. The highest productivity is reported in the variant with non prick out seedlings. In both tested genotypes highest productivity was accounted in sowing the seeds of 15 March - $3874.5 \mathrm{~kg} \mathrm{ha}^{-1}$ and $3332.7 \mathrm{~kg} \mathrm{ha}^{-1}$ for Plovdiv and for Obrazec 1, respectively, followed by the sowing of 1 March. In the last period of direct outdoor sowing the most fruits were received for Plovdiv and the yield reached to $3870.5 \mathrm{~kg} \mathrm{ha}^{-1}$ and for Obrazec 1 - $3418.4 \mathrm{~kg} \mathrm{ha}^{-1}$. Relatively high results were also obtained in the middle date of sowing $-3418.4 \mathrm{~kg} \mathrm{ha}^{-1}$ for the first variety and $3294.2 \mathrm{~kg} \mathrm{ha}^{-1}$ for the other.

Cape gooseberry fruits are characteristic with very good storage properties, possibly due to their specific morphological structure, wrapping the fruit from the withered shell sepals (Kendall, 2008). The role of calyx for storage and ripening of physalis was also reported by Rafael et al. (2006), arguing that the cape gooseberry is climacteric fruit, presenting peak respiration on 12 day after storage has begun. They recommended, for better preservation before storage, the calyx to be dried with treatment by $24^{\circ} \mathrm{C}$ and it is the most efficient measure since the fruit presented minor respiration rates as compared to fruit with calyx dried at $18^{\circ} \mathrm{C}$.

By applying the storage of ripe fruit it is designed to achieve continuous supply of fruits of cape gooseberry, in the period outside of the growing season and direct harvests. By the reason of the high demand for quality of cape goseberry fruits necessitate the search for a better understanding of fruit behavior. Furthermore, postharvest quality properties play an important role in meeting consumer demands (Garzón-Acosta et al., 2014).
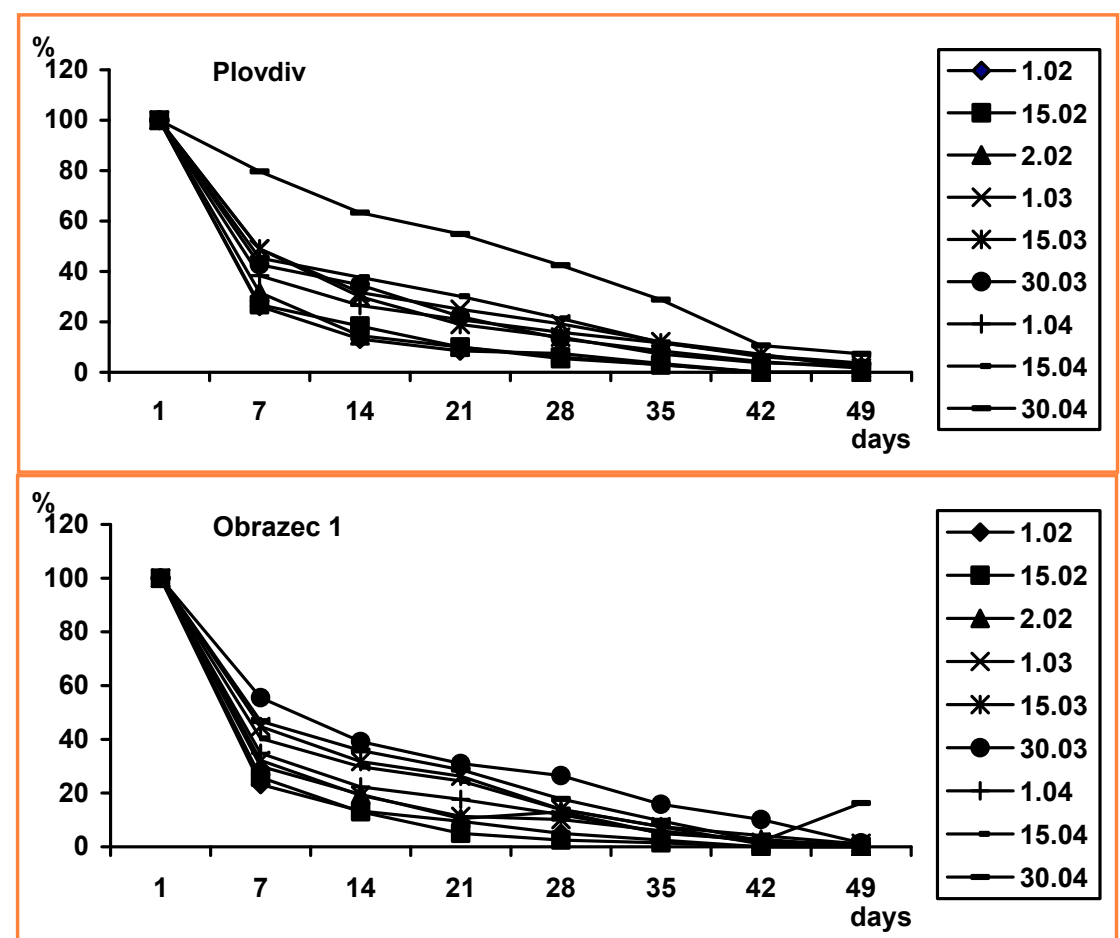

Figure 1 Storability of cape goosberry fruit under different techologies of growing

They achieve storage of the fruit for a period of 30 days at temperatures from $1{ }^{\circ} \mathrm{C}$ and $19^{\circ} \mathrm{C}$ and humidity of $68 \%$.

Different ways of farming have some influence on storability of the cape gooseberry fruits (Figure 1). Most major losses in all the variants were observed on the seventh day. The fruits of plants grown by pricking seedlings with different periods of sowing in both varieties showed comperatively low storability - approximately between $26 \%$ to $30 \%$. In the fruits from Plovdiv, grown by non pricking seedlings the significantly high storability, accounting of 7 days, approximately $50 \%$ of the initial amount of fruit was observed. Some stabilization occurred on 14 and 21 days and storage continued until 49 days in all periods of sowing. For fruit from Obrazec 1 storability was slightly lower. On 15 March variant storage lasted until 42 day, and for others as well as in previous cultivar to 49 day. Reduction in the rate of loss was also observed during the period of 14-28 days. Best storage was established for fruits from the second and third date of direct outdoor sowing of variety Plovdiv - on the seventh day more than $70 \%$ of the initial weight were preserved, while for the first date - it was around $40 \%$. With this growing technology significantly quantities were preserved already on the 21 and 28 days. Hernando et al. (2015) observed shorter period of storage - to 18 days in experiments with of cape gooseberry fruits, ecotype Columbia. However, in our investigation the storage continued up to 49 day, as a percentage of preserved fruit was approximately 5-7\%. In Obrazec 1, although the storability compared to the other variety was lower. The fruit from direct outdoor sowing was also preserved better, especially on the date 30 April. These differences may be related to different degrees of aging of the plant from which fruits are placed for storage. Plants from pricked out seedlings are the old and the fruits are from 2 or 3 harvests and those from direct sowing were practically the first picked fruits.

Cape gooseberry is a vegetable crop in which not all fruits under Bulgarian condition can mature by the end of the growing season. Formation and ripening of fruits have a direct relationship with the applied 
Table 2

Cape goosberry fruits for after harvest ripening

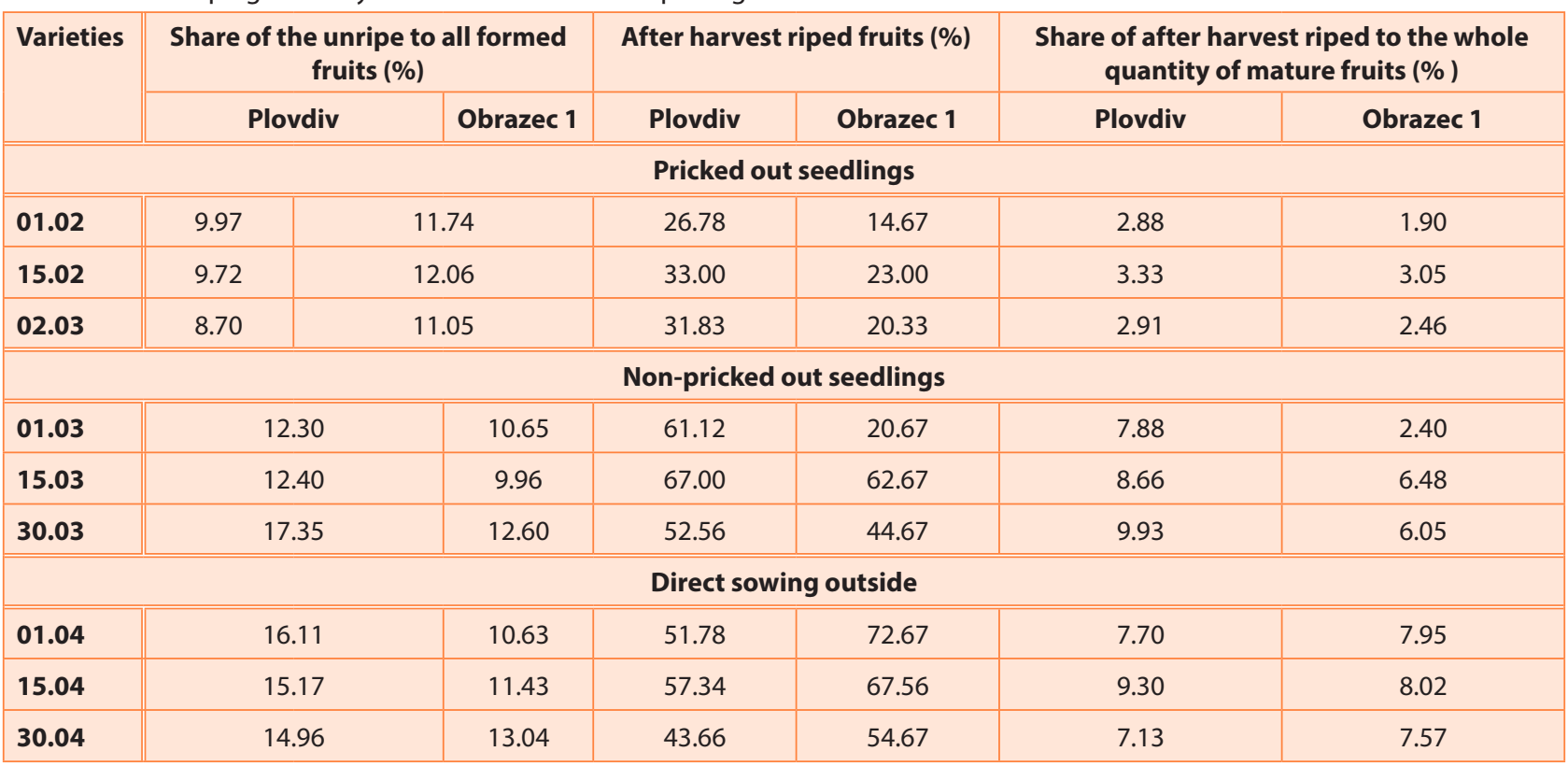

technology and it is important for the ripening process (Sahoo et al., 2002). Valdenegro et al. (2012) also said that this crop belongs to climacteric fruit, but not all of them matured enough and the process of maturation and its ripening is regulated by ethylene.

Production of cape gooseberry with different means of growing substantially affect the amount of unripe fruits (Table 2). At least they were in the variants with pricking out of seedlings, and their portion was highest in direct sowing outside. This could be due to the fact that the growing season in the cultivation with pricking out of seedlings is longer, the majority of fruits can ripen, and on the other hand by direct sowing outside the plants are phenologically younger and they set most fruits at the end of the growing season and therefore the numbers of harvests are lower. Differences between the two genotypes are almost nonexistent, but the quantity of unriped fruits is higher in variety Plovdiv. At least they were in plants of pricked out seedlings and most of them were in direct sowing. The proportion of unripe fruits, to all formed was higher for Plovdiv, except when the seedlings were pricked out. It was from 12.3\% (01 March) to $17.35 \%$ (30 March) for non-pricked out seedlings, and intermediate position took the fruits from direct sowing outside. In non-pricked out seedlings of Obrazec 1 sown on, 30 March and 15 March this proportion was between 12.6\% and $9.96 \%$, respectively. These not small amounts suggest that after harvest ripening of fruit it is required practice in cape gooseberry and very important with high significance for prolongation of the period for proposing fresh cape goosberry fruits.

As a result of conducting the after harvest ripening, the percentage of riped fruits for variety Plovdiv was higher in non-pricked out plants (15 March - 67.0\%) and in direct sowing outside, while for Obrazec 1 it was observed from direct sowing outside (1 April - 72.67\%). It can be emphasized, for both genotypes, that as a consequence of after harvest ripening of fruit, the proportion of ripened fruits was significantly greater, approximately more than twice for those that are from non pricked out and by direct sowing outside plants, as compared with those of the pricked out seedlings.

The total quantity of ripe fruits by means of after harvest ripening practice increased. The proportion of after harvest ripe fruits was more significant for non pricked out seedlings and it was $9.93 \%$ in sowing date of Plovdiv on 30 March and $6.48 \%$ for Obrazec 1 on the previous date. Similar trend was observed for direct sowing outside, where as a result of the after harvest ripening the amount of suitable for consumption fruits has increased by $9.30 \%$ and 8.02\% at sowing on 15 April for Plovdiv and for Obrazec 1, respectively. Growing the cape gooseberry by direct sowing outside or by non pricked out seedlings, i. e. in case of a shorter vegetation period, on one hand it was characterized by a higher proportion of unripe fruit to all developed one, but on the other hand it was with a higher percentage of after harvest ripe. Therefore, more appropriate and economically efficient is the application of this practice in the above mentioned two types of cultivation. These results are extremely important in relation to the opportunities to extend the period of supply with fresh fruit.

In relationship to prolongation of the period of supplying with fresh fruit, high significance has also the dynamics of after harvest ripening (Figure 2). The most fruits from the both genotypes ripened on the seventh day and were obtained from the variant with non-pricked out seedlings, sown on $15.03-37.56 \%$ for Plovdiv and $35.0 \%$ for Obrazec 1. Secondly, for the first variety there were the fruits from the same type of seedlings, but sown on 1 March - 34.0\%, while for the other one was from direct sowing outside on 15 April $-34.33 \%$. After that day, the percentage of after harvest ripe fruits began to decrease gradually. After harvest ripening, even in insignificant amount detected until 35 days in Obrazec 1 in sowing date 30 March and in all terms of direct outside sowing, while for Plovdiv observed on 42 day, but in extremely low quantity $-0.89 \%$ and $0.67 \%$ in variants with pricked out seedling - 15 February and 2 March. 


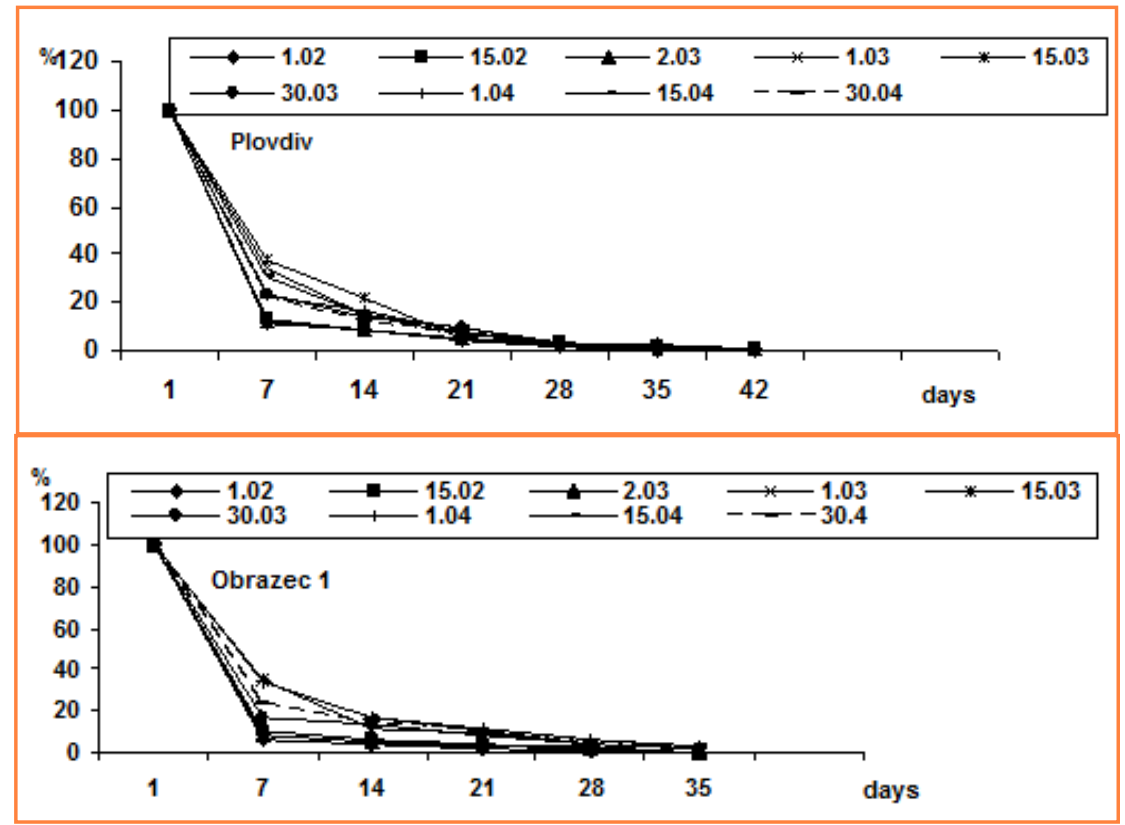

Figure 2 Dynamic of post-harvest ripening of cape goosberry fruit

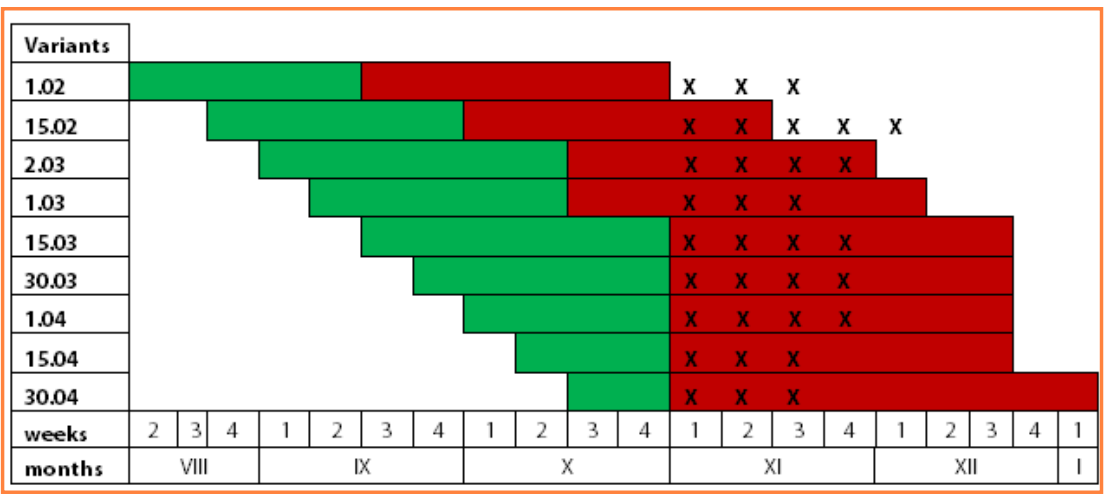

Figure $3 \quad$ Period of entry into production of cape gooseberry fruits of variety Plovdiv

Legend: $\square$-from harvests; $\mathbf{\square}$-from storage; $\mathbf{X X X}$-from post-harvest ripening

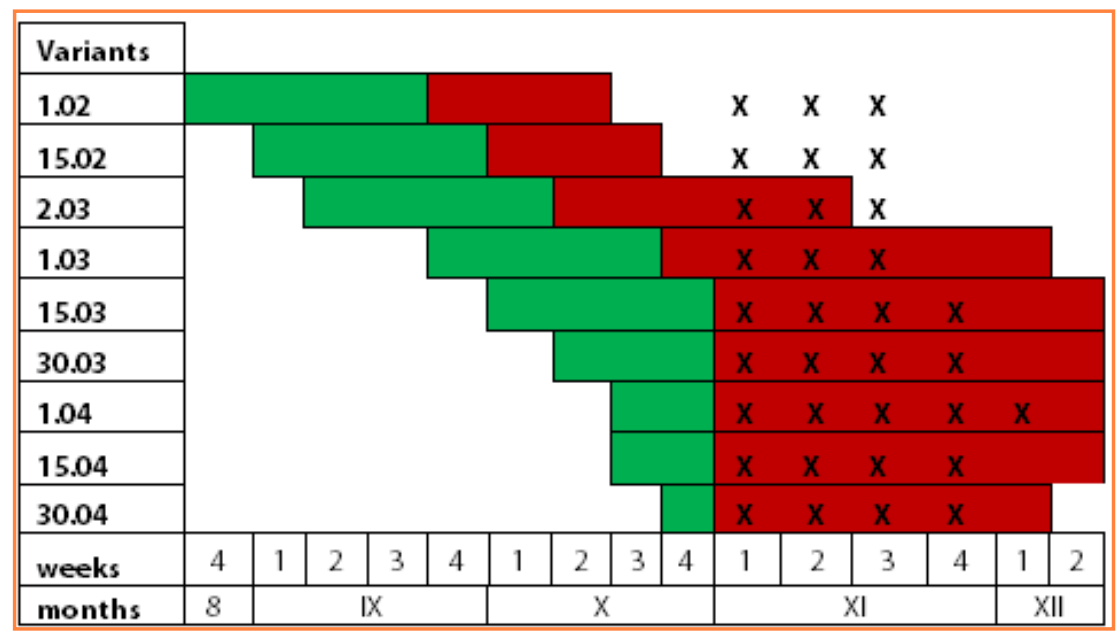

Figure 4 Period of entry into production of cape gooseberry fruits of Obrazec 1 Legend: $\square$-from harvests; $\mathbf{\square}$-from storage; XXXX -from post-harvest ripening
The earliest after harvest ripening completed in sowing of 15 March for non pricking out seedlings of Plovdiv still 28 days, while for Obrazec 1 on the same days for fruits from pricked out seedlings and for first date of nonpricked out. The highest decrease was observed between 7 and 14 days for date 1 March - with $18.88 \%$, followed by 15 April - with $16.0 \%$ of Plovdiv and for Obrazec 1 - of 15 March and 15 April with $23.33 \%$ and $17.78 \%$, respectively. Appropriate period for after harvest ripening was up to 21 days, when for Plovdiv obtained additional ripen fruit within $4.56 \%$ (1 February) to $9.56 \%$ (30 March), and for Obrazec 1 between $2.45 \%$ (1 February) to $11.33 \%$ (1 April).

Through growing cape gooseberry by different technologies and time of sowing, and the possibility of storage and ripening are achieved proposing of the fresh fruits in a relatively long period of time. Application of these techniques to extend the possibility of continuous supply of the market was also reported by Fisher et al. (2011). In Figures 3 and 4 are presented chronologically entering production, both direct harvest and in result of storage and after ripening. With pricking out of the seedlings, the harvest of Plovdiv started between the second and fourth week of August, depending on the term of sowing. Average period during which you can receive fruit from harvest was five to six weeks. The harvests of the first dates of sowing were completed much earlier. Then, there is the possibility to store the fruit to six weeks and for different vartiants, it starts from mid - September to mid - October and ends from the beginning to the end of November. The period for submission of production was extended aditionally by another three weeks as a result of post-harvest ripening, although there was some overlap with the fruits of storage.

In non pricking out seedlings, harvesting period is from the first and third week of September and the average duration is again five to six weeks, after which the plants fruiting decreases. The storage of these fruits is relatively better - an average of seven weeks. This makes it possible to offer the fruit from the middle of October to the third week of December. In this way of growing by the additional post- 
harvest maturity the amount of fruits provided from storage in November was increased, because existing coincidence in obtaining of the ready fruits in these two approaches.

The harvest from direct outdoor sowing began at the latest - from the first to the third week of October, depending on the term of sowing. This reduces the number of harvests due to the onset of autumn frosts, as the latest date it is only one harvest. The possibility for storage the fruits from the first two dates, similar to the previous technology was seven weeks on average - from the beginning of November to the third week of December. Despite the short period of harvest, the fruits obtained from the latest sowing provide the opportunity for significant long-term storage, which continues until the first week of January. In this technology the quantity of immature fruit was higher. The ready fruits from post-harvest ripening were received in the same period as those from storage, but thus the amount of fresh fruit is increased during the first three weeks of November, while from the first date of sowing until the end of the month. The production of cape gooseberry of Plovdiv can be marketed for a long time. From direct harvest it comes from the first week of August to the end of October and from storage and supplement of fruit from additional ripening - from mid - September to early January, which is the average of five months.

The harvests of Obrazec 1 grown by pricked out seedlings began two weeks later compared with Plovdiv and continued for about a month. Depending on the term of sowing this was from the last week of August until the first of October. The period of storage of the fruit of the first two dates is significantly shorter than the one reported for Plovdiv - three weeks. The fruits of the last date have good storage and it continues up to five weeks. The fruits of pricked out seedlings were stored from late September to mid November. In this genotype, however, the importance of ripening is much more significant, further, after completion of the storage, for a further three weeks of November new very good fruit were obtained.

The harvests of non-pricked out seedlings were from the last week of September, while the later sowing delayed by a week, continued for a month. For the last date that period was shorter as a result of falling autumn frosts. Storability of the fruits of this genotype was shorter than that of Plovdiv and these variants had duration of five weeks, covering the period from late October to mid - December. The production post-harvest ripening was obtained simultaneously with that of storage and also contributed to increasing the quantities of fresh fruit for three or four weeks in November. In the earlier dates of sowing in pricking as well as non pricking seedlings mass fruiting ends earlier.

From direct outdoor sowing the fruits began to come from mid - October for two earlier dates, and for the latest in the last week of the month. Due to worsening weather conditions and the inability to mature more fruits, only one harvest was carried out. Storage is shorter than that of the Plovdiv and finished after five to six weeks - from early November until mid - December. The fruits from direct sowing ripen weaker and for them post-harvest ripening is much more relevant implementing. It also establishes the overlap of fruits from storage with those of additional ripening and this is throughout November, while for the first date of direct sowing also in the first week of December.

Fruit of the direct harvest of Obrazec 1 were obtained from late August to late October, and by storage from the end of September to the mid - December. In November it was observed simultaneously receiving the fruits from additional ripening and storage, with the exception of variants with pricking seedlings. With this the proposed quantities of fresh fruit quantities of fresh fruits were increased. The time during which may be provided products from Obrazec 1 is an average of a little more than four months.

\section{Conclusion}

The productivity of cape gooseberry under cultivation by non pricking seedlings or by direct outdoor sowing was higher. The Plovdiv variety is characterized with higher yield.

The storability depends on the type of farming. Cape gooseberry fruits from plants grown by direct outdoor sowing, primarily form variety Plovdiv, were characterized with the highest storability, and with the weaker one were those grown by pricking out.

The portion of unripe fruits in growing through direct sowing and non pricking seedlings was higher, especially in variety Plovdiv.

The period of supply of fresh cape gooseberry fruit was from 4 to 5 months, from direct harvests in variety of Plovdiv it was three months - from August to the end of October and for Obrazec 1 it was two months - September and October. During the rest of the above mentioned period the fruits come from storage or from additional ripening, as the greater part is obtained as a result of storage.

\section{References}

CARVALHO, C. P. - VILLAÑO, D. - MORENO, D. A. - SERRANO, M. - VALERO, D. 2015. Alginate edible coating and cold storage for improving the physicochemical quality of cape gooseberry (Physalis peruviana L.). In Journal of Food Science and Nutritions, vol. 1, pp. 102-112. ISSN 2048-7177.

CHERNOOK, L. G. 1997. Tomato, pepper, eggplant, cape gooseberry. In Series Vitalis, pp. 288. ISBN 1156-258-369.

CHRISTOV, Ch. 2010. Cape goosverry - Physalis peruviana L. In Seeds of rare and unknown fruits and vegetables. Available at: www.hobi-semena.com (accessed March, 2010). ISSN 6853-2569.

FISCHER, G. - HERRERA, A. - ALMANZA, P. J. 2011 Cape gooseberry (Physalis peruviana L.). In Postharvest biology and technology of tropical and subtropical fruits, vol. 2, pp. 374-396. ISSN 978-1-84569-733-4.

FOWEL, J. - COHEN, L. 1992. Practicle statistics for field biology. New York : John Wiley \& Sons. 223 p. ISBN 978-1-118-30055-8.

GARZÓN-ACOSTA, C. P. - VILLARREAL-GARZÓN, D. M. - FISCHER, G. - HERRERA, A. O. - SANJUANELO, D. W. 2014. Deficiencies of phosphorus, calcium and magnesium affect the postharvest quality of cape gooseberry (Physalis peruviana L.) fruits. In Acta horticulturae, vol. 1047, pp. 208-216. ISSN 0567-7572.

HERNANDO, P. E. - REYES, A. J. - ÁlVAREZ-HERRERA, J. G. - LEGUIZAMO, M. F. - JOYA, J. G. 2015. Comportamiento del fruto de uchuva Physalis peruviana L., bajo diferentes temperaturas de almacenamiento. In Revista de Ciencias Agrícolasta, vol. 32, no. 2, pp. 26-35. ISSN 2238-1171.

IVANOVA, V. - PANCHEV, V. - TABASHKA, T. 2014. The influence of the term of seed harvesting of lime (Tilia ssp.) on the vegetative 
behaviours of seedlings. In Scientific works of Union of Scientist of Bulgaria, ser. Techniques and technology, vol. 12, pp. 310-16. ISSN 1311-9192.

JAEGER, P. 2001. Study of the Market For Rwandan Physalis In Europe. New York : ADAR Agribusiness Centre, $p$ 17. ISBN 879-235-123-7.

KENDALL, H. 2008. Cape gooseberry. In Kendall farm. Available at: http://www.kendallfarms.com.au/home2.htm (accessed October, 2008). ISSN 8421-3852.

KLINAC, N. J. - WOOD, F. H. 1986. Cape Gooseberry (Physalis peruviana L.). In Orchardist of New Zealand, vol. 59, pp. 103. ISSN 0110-6260.

McCAIN, R. 1993. Goldenberry, passion fruit, \& white sapote: Potential fruits for cool subtropical areas. In New Crops, edited by J. Janick and J.E. Simon. New York, John Wiley and Sons, pp. 479486. ISBN 0-471-59374-5.

MORTON, J. F. 1987. Cape gooseberry. In: Fruits of Warm Climates, edited by J.F. Morton. Winterville : Creative Resource Systems, Inc, pp. 430-434. Available at: http://www.hort.purdue.edu/newcrop/ morton/cape gooseberry.html (accessed May 21, 2007).

NOVOA, R. H. - BOJACA, M. - GALVIS, J. A. - FISCHER, G. 2006. Fruit maturity and calyx drying influence post-harvest behavior of Cape gooseberry (Physalis peruviana L.) stored at $12{ }^{\circ} \mathrm{C}$. In Agronomía Colombiana, vol.24, no. 1, pp. 77-86. ISSN 0120-9965.

PANAYOTOV, N. - TCORLIANIS, S. 2000. The effect of type of seedlings and of the planting scheme on productivity and quality of tomatilo (Physalis peruviana L.) grown under Bulgarian condition. In Acta Horticulture, vol. 579, pp. 373-376. ISSN 0567-7572.

PANAYOTOV, N. - PEVICHAROVA, G. 2002. Investigation on the possibilities for cape gooseberry (Physalis peruviana L.) post-harvest storage. In Proceeding of the First Symposium of Horticulture, 1620 October 2002, Ohrid, Republic of Macedonia, pp. 634-637. ISBN 0567-7572.

PATEL, P. R. - NEETA, B. G. - TADAPANENI, V. - RAO, R. 2011. Physiochemical changes in sunberry (Physalis minima L.) fruit during growth and ripening. In Fruits, 2011, vol. 66, pp. 37-46. ISBN 965-895-2658-6-7.

PEIRIS, K. H. S. - MALLON, J. L. - KAYS, S. L. 1999. Raspiratry rate and vital heat of some specially vegetables at various storage temperatures. In HortTechnology, vol. 7, no. 1, pp. 46-49. ISSN 1063-0198.
RAFAEL, H. N. - MAURICIO, B. - JESÚS, A. G. - GERHARD, F. 2006. La madurez del fruto y el secado del cáliz influyen en el comportamiento poscosecha de la uchuva, almacenada a $12{ }^{\circ} \mathrm{C}$ (Physalis peruviana L.). In Agronomia Colombia, vol. 24, no. 1, pp.138-145. ISSN 0120-9965.

RAMADAN, M. F. - MOERSEL, J. T. 2007. Impact of enzymatic treatment on chemical composition, physicochemical properties and radical scavenging activity of goldenberry (Physalis peruviana L.) juice. In Journals of Science for Food Agriculture, vol. 87, pp. 452-460. ISSN 1097-0010.

RAMADAN, M. F. 2011. Bioactive phytochemicals, nutritional value, and functional properties of cape gooseberry (Physalis peruviana). In Food Research International, vol. 44, pp. 1830-1836. ISSN 0963-9969.

SAHOO, D. P. - MAHAPATRA, A. K. DAS - SAHOO, N. R. 2002. Effect of nitrogen and potassium on growth and yield of tomato (Lycopersicon esculentum Mill.) Var. Utkal Kumari. Haryana. In Journal of Horticultural Science., vol. 31, no. 3-4, pp. 264-266. ISSN 1611-4426.

SARKAR, T. K. - PRADHAN, U. - CHATTOPADHYAY, T. K., 1993. Storability and quality changes of capegooseberry fruit as influenced by packaging and stage of maturity. In Annals of Agricultural Research, vol. 14, no. 4, pp. 396-401. ISSN 0570-1783.

SHOPOVA, N. - CHOLAKOV, D. - HAYTOVA, D. 2014a. Productivity of the plants for late field tomato production depending on the age and planting area of the seedling. In Journal of International Scientific Publications: Agriculture and Food, vol. 2, pp.179-191. ISBN 879-235-123-7.

SHOPOVA, N. - CHOLAKOV, D. - HAYTOVA, D. 2014b. Effect of the composition of seedlings mixture on the physiological behaviour and photosynthetic productivity of tomato plants. In Journal of International Scientific Publications: Agriculture and Food, vol. 2, pp.171-178. ISBN 879-235-123-7.

VALDENEGRO, M. - FUENTES, L. - HERRERA, R. - MOYA-LEÓN, M. A. 2012. Changes in antioxidant capacity during development and ripening of goldenberry (Physalis peruviana L.) fruit and in response to 1-methylcyclopropene treatment. In Postharvest Biology and Technology, vol. 67, pp. 110-117. ISSN 0925-5214. 